\title{
Kepemimpinan Lurah Wanita Dalam Jabatan Publik
}

\author{
1Prihati, ${ }^{2}$ Nurpeni, ${ }^{3}$ Fara Merian Sari \\ ${ }^{123}$ Fakultas Ilmu Administrasi, Universitas Lancang Kuning, Indonesia \\ e-mail:prihati@unilak.ac.id
}

\begin{abstract}
Abstrak
Fenomena yang peneliti temui dilapangan berkaitan dengan bagaimana seorang pemimpin perempuan berkoordinasi,berkomunikasi dan menyeimbangkan antara karir dan rumah tangga, serta kultur yang kurang mendukung wanita bekerj.Konsep teori dalam dalam penelitian ini mengacu pada konsep kepemimpinan. teknik pengumpulan datanya melalui observasi dan wawancara mendalam. Adapun jenis penelitian dilakukan melalui pendekatan deskriptif Kualitatif. Berdasarkan hasil penelitian bahwa ibu lurah harus lebih intensif melakukan pendekatan pendekatan kepada pegawainya,melalui komunikasi yang intensif,selalu memotivasi pegawai dalam bekerja dan mengutamakan disiplin dan kejujuran kepada pegawai. Hambatan yang dimiliki ibu lurah berasal dari kurangnya sarana dan prasarana kantor kelurahan,usia ibu lurah yang relative muda sehingga sulit berkomunikasi dengan pegawai yang lebih tua dan hambatan ekternal kantor kelurahan. saran penulis adalah bahwasanya ibu lurah harus lebih intensif melobi kepala kecamatan untuk kelengkapan sarana prasarana kantor, harus bisa lebih mempengaruhi pagawai dalam kebijakan kebijakannya.
\end{abstract}

Keywords: kepemimpinan, Lurah, Wanita, Publik

\begin{abstract}
The phenomenon that the researchers encountered in the field relates to how a woman leader coordinates, communicates and balances career and household, as well as a culture that is less supportive of working women. The theoretical concept in this study refers to the concept of leadership. data techniques through observation and in-depth interviews. The type of research is carried out through a descriptive qualitative approach. Based on the results of the study, the village head must be more intensive in approaching employees, through intensive communication, always motivating employees to work and prioritizing discipline and honesty to employees. The obstacles faced by the village head came from the facilities and infrastructure of the village office, the relatively young age of the village head, making it difficult to communicate with older employees and external obstacles to the village office. The author's suggestion is that the village head should be more intensive in lobbying the head of the subdistrict for the completeness of office infrastructure, it should influence staff more in policy policies.
\end{abstract}

Kata Kunci : leader, Lurah, women, public 


\section{PENDAHULUAN}

Peranan dan posisi perempuan dan laki-laki di era kemerdekaan ini cukup seimbang. Para wanita tidak lagi dikondisikan sebagai perempuan yang hanya mengurus rumah tangga saja, tetapi lebih tinggi lagi yaitu diikutsertakan dalam proses pembangunan.

Jumlah perempuan yang mengikuti pendidikan formal makin bertambah. Seiring dengan bertambahnya jumlah perempuan dalam menempuh pendidikan formal, mengakibatkan bertambahnya jumlah wanita yang mengisi perannya dalam jabatan publik. Kota Pekanbaru yang memiliki luas wilayah $632,27 \mathrm{~km}^{2}$ dengan jumlah penduduk sebanyak 886.226 jiwa (wikipedia.org tahun 2018), memiliki 12 kecamatan dan 83 kelurahan.

Alasan penulis meneliti di Kelurahan Limbungan Kecamatan Rumbai pesisir dikarenakan kepala kelurahannya adalah wanita dan Kelurahan Limbungan merupakan wilayah pemekaran dari Kecamatan Rumbai Pesisir sehingga penulis tertarik untuk meneliti di Kelurahan Limbungan Kecamatan Rumbai pesisir.

Kelurahan Limbungan yang merupakan satu dari 8 kelurahan yang ada di kecamatan Rumbai pesisir, kepala kelurahannya memiliki tugas :

1. Melaksanakan kegiatan pemerintahan kelurahan

2. Melakukan pemberdayaan masyarakat

3. Melakukan pelayanan masyarakat

4. Memelihara ketentraman dan ketertiban umum

5. Memelihara sarana dan prasarana serta fasilitas pelayanan umum

Tabel 1 jenis pelayanan target dan realisasi pelayanan di Kantor Kelurahan Limbungan Rumbai Pekanbaru

\begin{tabular}{|l|l|l|l|}
\hline No & \multicolumn{1}{|c|}{ Jenis Pelayanan } & \multicolumn{1}{|c|}{ Target } & \multicolumn{1}{|c|}{ Realisasi } \\
\hline 1 & Surat pengantar Permohonan KK & 15 menit & 60 menit \\
\hline 2 & Surat pengantar Permohonan KTP & 15 menit & 60 menit \\
\hline 3 & Surat Pengantar Permohonan SKCK & 15 menit & 60 menit \\
\hline 4 & Surat Pengantar Permohonan Akta kelahiran & 15 menit & 60 menit \\
\hline 5 & Surat Pengantar Izin Usaha Dagang & 15 menit & 60 menit \\
\hline 6 & Surat Pengantar Domisili/Penduduk & 15 menit & 60 menit \\
\hline 7 & Surat Keterangan Waris Tanah & 60 menit & 120 menit \\
\hline
\end{tabular}

Sumber, Kantor Kelurahan Limbungan Kecamatan Rumbai,Pekanbaru 2019

Tabel diatas memperlihatkan realisasi pelayanan yang sudah dibuat kantor Kelurahan belum sesuai seperti apa yang diharapkan. Padahal kelurahan mengedepankan pelayanan prima .Realisasi pelayanan akan lebih lama lagi waktu penyelesaian nya apabila masyarakat tidak melengkapi dokumen dokumen sesuai persyaratan.

Fenomena yang penulis temui saat prasurvey terlihat dari realisasi pelayanan kepada masyarakat yang belum memenuhi target sesuai dengan yang di inginkan, belum pernah mendapat penghargaan penghargaan dalam berbagai perlombaan, disamping itu juga ibu lurah belum dapat menyeimbangkan antara karir dan rumah tangga, serta kultur yang kurang mendukung wanita bekerja.. 


\section{METODE}

Penelitian ini dilakukan di lokasi kantor Lurah Limbungan Kecamatan Rumbai Pesisir Kota Pekanbaru. Penelitian ini dilakukan dengan pendekatan deskriptif kualitatif. Penelitian untuk mengetahui dan menganalisis tentang Kepemimpinan lurah wanita Dalam Jabatan Publik Di Kantor Kelurahan Limbungan Kecamatan Rumbai Pesisir Kota Pekanbaru. Teknik Pengumpulan Data Pengamatan langsung, Wawancara, dokumentasi. Analisa data kualitatif adalah proses mencari dan menyusun secara sistematis data yang di peroleh dari hasil wawancara, catatan lapangan dan bahan-bahan lain sehingga mudah di pahami dan temuannya dapat di informasikan kepada orang lain dengan cara mengorganisasian data kedalam kategori menjabarkan kedalam unit-unit, melakukan sintesa, menyusun kedalam pola, dan membuat kesimpulan sehingga mudah dipahami oleh diri sendri maupun orang lain (Sugiyono, 2005:89).

\section{HASIL DAN PEMBAHASAN}

\subsection{Hasil}

Kelurahan menurut Peraturan daerah kota Pekanbaru nomor 9 tahun 2016 adalah di pimpin oleh lurah yang berada dibawah dan brtanggung jawab kepada walikota melalui Camat. Lurah sebagaimana dimaksud diatas diangkat dan diberhentikan sesuai dengan ketentuan perundang undangan yang berlaku.

Kelurahan menurut Perda Kota Pekanbaru Tahun 2016 Bab V pasal 13 terdiri dari :

1) Lurah

2) Sekretaris Lurah

3) Seksi Pemerintahan ketentraman dan Ketertiban

4) Seksi Kesejahteraan Sosial

5) Seksi Pembangunan dan Pemberdayaan Masyarakat Adapun tugasdan fungsi lurah mencakup :

Tugas dan Fungsi Membantu Camat dalam menyelenggarakan tugas umum pemerintahan dan tugas pembantuan lainnya.

a) Penyelenggaraan urusan pemerintahan ,ketentraman dan ketertiban pemberdayaan masyarakat serta urusan yang dilimpahkan camat.

b) Perencanaan program kerja pemerintahan ketentraman dan ketertiban kelurahan

c) Pengkoordinasian kegiatan pemberdayaan masyarakat.

d) Pelaksanaan pelayanan masyarakat.

Jabatan sebagai kepala kelurahan biasanya dilakukan oleh para kaum pria. Namun hal ini tidak menutup kemungkinan jabatan lurah dipercayai kepada kaum wanita. Hal ini terjadi di Kecamatan Limbungan Kota Pekanbaru.Ditangan dingin lurah wanita ini,organisasi kelurahan dapat berjalan dengan baik.Berikut petikan wawancara penulis yang berkaitan dengan kepemimpinan Lurah wanita dalam jabatan publik di kantor Kelurahan Limbungan Kecamatan Rumbai Pesisir Kota Pekanbaru.

a. kemampuan mempengaruhi orang lain/bawahan

"dalam mempengaruhi pegawai supaya mengerti atas perintah yang saya buat ,saya melakukan pendekatan dengan menjelaskan perintah saya dengan bahasa yang mudah dimengerti . Saya akan bersikap bijaksana jika ide ide, saran saran saya tidak disetujui pegawai dan saya akan berusaha menjelaskan lebih detail lagi, keputusan diambil secara musyawarah. Saya pernah mengikuti latihan kepemimpinan beberapa kali." 
b. Kemampuan mengarahkan tingkah laku bawahan/orang lain.

" pegawai yang bermasalah dalam tingkah lakunya ,akan saya panggil keruangan saya,akan saya nasehati,saya gambarkan sisi negative/dampaknya,jika tingkah lakunya tidak berubah,ada beberapa pegawai yang beberapa kali saya panggil,baru menyadari akan kesalahannya."

c. Mencapai tujuan organisasi /kelompok

" bersama sama pegawai melalui rapat,workshop,seminar dan pertemuan pertemuan informal guna mencapai tujuan kantor kelurahan .walaupun sering terjadi perdebatan terutama dengan pegawai yang sudah senior ,yang penting komunikasi yang intensif dengan pegawai, dan tujuan dapat tercapai”

Dari hasil wawancara dengan ibu lurah dapat ditarik kesimpulan bahwa kemampuan ibu lurah dalam mempengaruhi,mengarahkan dan mencapai tujuan organisasi sudah baik. Sebagai pimpinan yang baik melakukan pendekatan pendekatan yang intensif kepada pegawainya,melalui komunikasi yang intensif,selalu memotivasi pegawai dalam bekerja dan mengutamakan disiplin dan kejujuran kepada pegawai.

a. kemampuan mempengaruhi orang lain/bawahan

" dalam mempengaruhi pegawai ibu lurah melakukan pendekatan dengan bahasa yang mudah dimengerti. Beliau bersikap bijaksana jika ide ide, saran saran nya tidak disetujui pegawai biasanya, keputusan diambil secara musyawarah."

b. Kemampuan mengarahkan tingkah laku bawahan/orang lain.

" pegawai yang bermasalah dalam etika dan tingkah lakunya ,akan di panggil keruangannya dan ,akan di nasehati,"

c. mencapai tujuan organisasi /kelompok

" bersama sama pegawai selalu intensif berkomunikasi biasanya melalui rapat,workshop,seminar dan pertemuan pertemuan informal.

\section{Masyarakat}

" sejak beliau memimpin kelurahan,banyak kemajuan kemajuan yang kami rasaka,kami sering melihat ibu lurah turun langsung melihat pekerjaan yang dilakukan pegawai . ibu lurah kami terkenal dengan keramahannya"

Hambatan yang dimiliki ibu lurah dalam memimpin kelurahan berasal dari kurangnya sarana dan prasarana kantor untuk pekerjaan pegawai.Usia ibu lurah yang relative masih muda,sehingga banyak segannya kepada pegawai yang relative senior dalam berkomunikasi. hambatan ekternal kantor kelurahan yaitu hambatan dari keluarga,yang sering diprotes keluarga baik anak anak atau suami,biasanya ketika terjadi permasalahan yang cukup berat yang membutuhkan waktu yang cepat untuk penyelesaiannya biasanya bu lurah akan bekerja lebih lama dari jam bekerja. Ini yang sering mendapat protes keluarga. 


\subsection{Pembahasan}

1.Kemampuan mempengaruhi orang lain/bawahan

Mempengaruhi orang lain atau pada dasarnya bisa dilakukan oleh siapa saja, demikian jasa dengan pemimpin, sudah pasti harus bisa mempengaruhi bawahannya, yang terpenting seorang pemimpin harus memiliki prinsip dalam mempengaruhi orang lain. Seandainya tidak memiliki prinsip sudah pasti akan mudah dipengaruhi bawahan. Apabila pengaruhnya baik tidak menjadi masalah, yang menjadi permasalahan adalah apabila pengaruhnya negatif.

Dari hasil penelitian penulis melalui wawancara kepada kepala kelurahan yaitu ibu welfina sari, S.AP, beliau dalam mempengaruhi bawahannya, selalu melalui pendekatan dalam bahasa yang mudah di mengerti dari hasil wawancara, beliau mengakui dengan usianya yang relative lebih muda di banding egawai-pegawainya, terkadang ada mis communication dalam berkomunikasi dengan pegawipegawainya, terutama pegawai yang usianya di atas usia ibu lurah. Dari hasil wawancara dengan pegawai dan masyarat, mereka juga mengatakn, ibu lurah selalu menggunakan bahasa yang mudah di megerti dalam berkomunikasi. Walaupun kadang-kadang ada juga pertentangan dengan pegawai.

Dari keterangan ibu lurah pegawai dan masyarakat di atas jelaslah bahwasanya seorang pemimpin itu dalam berkomunikasi harus memiliki prinsip, untuk mempertahankan prinsip harus memiliki sebuah inisiatif bagaimana mempengaruhi orang lain/bawahan sehingga mau mengikuti apa yang pimpinan katakan.

2.Kemampuan mengarahkan tingkah laku bawahan.

Semakin banyak bawahan dalam suatu organisasi, akan semakin banyak dan beragam tingkah lakunya ke dalam organisasi. Dari hasil wawancara penulis dengan ibu lurah, pegawai dan masyarakat apabila ada pegawai yang bertingkah laku kurang baik di kantor, maka ibu lurah akan memanggil pegawai tersebut, untuk dinasehati dan ini efektif di lakukan oleh pimpinan dalam memperbaiki tingkah laku pegawai.

Dari keterangan di atas jelaskan bahwasanya seseorang seorang pimpinan itu harus bisa mengarahkan pegawainya yang bermasalah dengan tingkah lakunya. Dengan memperlihatkan tingkah laku yang baik kepada bawahan, maka pimpinan bisa mempengaruhi tingkah laku bawahan.

\section{Mencapai tujuan Organisasi}

Salah satu tujuan organisasi, terutama organisasi publik adalah mencapai tujuan organisasi. Semua komponen sumber daya manusia yang ada dalam organisasi bersama-sama bersatu pada mewujudkan tujuan organisasi.Dari hasil wawancara cara pimpinan mencapai tujuan organisasi melalui rapat-rapat, baik rapat-rapat yang bersifat formal, maupun yang bersifat informal, disamping itu juga mengikuti seminar dan warh shop.

Dari keterangan di atas jelaslah bahwa cara mencapai tujuan organisasi melalui rapat-rapat, seminar-seminar, worhshop, merupakan cara yang efektif untuk mencapai tujuan yang tidak kalah pentingnya adalah pimpinan harus terus memantau kinerja pegawai, agar tenis bekerja sesuai dengan ilmu yang baru dimiliki pegawai melalui rapat-rapat, seminar dan warhshop. 


\section{KESIMPULAN}

Dari hasil penelitian dapat ditarik kesimpulan bahwa lurah harus lebih intensif melakukan pendekatan pendekatan kepada pegawainya, melalui komunikasi yang intensif, selalu memotivasi pegawai dalam bekerja dan mengutamakan disiplin dan kejujuran kepada pegawai. Hambatan yang dimiliki ibu lurah berasal dari kurangnya sarana dan prasarana kantor kelurahan,usia ibu lurah yang relative muda dan hambatan ekternal kantor kelurahan.

\section{SARAN}

Melakukan lobi dengan kepala kecamatan untuk kelengkapan sarana dan prasarana kantor kelurahan.sering melakukan pelatihan pelatihan kepemimpinan supaya lebih banyak lagi memiliki skill kepemimpinan. Disarankan ibu lurah untuk memberikan pengertian yang lebih intensif lagi kepada keluarga akan tanggung jawab yang di emban oleh ibu lurah. Memberikan pengertian kepada anak anak ketika terjadi permasalahan dikantor yang membutuhka penyelesaian yang cepat.

\section{DAFTAR PUSTAKA}

[1]. Danim,Sudarwin ,2004,motivasi,kepemimpinan dan efektifitas Kelompok,PT Rineka Cipta Jakarta.

[2]. Handoko, T, Hani, 1995. Manajemen Personalia Dan Sumber Daya manusia. Yokyakarta, BPFE.

[3]. Handoko, T, Hani, 2003. Manajemen Edisi 2. Yokyakarta, BPFE YK.

[4]. Hamalik ,Oemar,2001,Pengembangan Sumber Daya Manusia manajemen Pelatihan Ketenagakerjaan,Pendekatan Terpadu,Bumi Aksara Jakarta

[5]. Innu Kencana Syafi'ie,2009,Kepemimpinan pemerintahan Indonesia,Refika aditama,bandung

[6]. kartono,Kartini,2014,pemimipin dan kepemimpinan,Raja grafindo Persada,Jakarta.

[7]. Sugiono, 2010. Metodologi Penelitian Administrasi, Jakarta, Bumi Aksara. 